[Agr. Biol. Chem., Vol. 30, No. 2, p. 186 192, 1966]

\title{
Intracellular Peptidase of Bac. subtilis
}

\author{
By Noshi Minamiura, Takehiko Yamamoto and Juichiro Fukumoto \\ Faculty of Science, Osaka City University \\ Received September 1, 1965
}

\begin{abstract}
A peptidase was isolated from the cells of amylase-producing Bac. subtilis by means of cell lysis with egg white lysozyme, followed by freezing and thawing, salting out, dialysis and ion-exchanger column chromatography. The enzyme required manganese ion to show the enzyme activity. Also the enzyme was stable in the presence of magnesium ion. The enzyme hydrolyzed various synthetic peptides by stepwise removal of the amino terminal amino acid of peptides and thus the peptidase was found to be aminopeptidase.
\end{abstract}

It is well known that aminopeptidase is widely distributed in various organisms. However, there have been only a few papers $^{11}$ on the nature of the enzyme with exception of the peptidase derived from animal kidney. Recently, a certain strain of Bac. subtilis, which has been reported to secrete a large quantity of proteinase ${ }^{21}$ as well as amylase $^{31}$ into media, was found to contain aminopeptidase in a substantial quantity in the cells.

The present paper deals with the method of purification and some properties of intracellular peptidase of the bacteria.

\section{MATERIALS AND METHODS}

As the source of enzyme, an amylase-producing bacterium, Bac. subtilis var, amyloliquefaciens FUKUMOTO, was used throughout the work. The bacteria were surface-cultured in a Fernbach's flask containing one 1 of medium consisted of $5 \%$ soybean cake extract, $3.5 \%$ dextrin, $0.8 \%\left(\mathrm{NH}_{4}\right)_{2} \mathrm{HPO}_{4}, 0.05 \%$ $\mathrm{CaCl}_{2}$ and $0.02 \%$ each of $\mathrm{MgSO}_{4} \cdot 7 \mathrm{H}_{2} \mathrm{O}$ and $\mathrm{KCl}$ in tap water $(\mathrm{pH} 7.0)$. After a forty hours' culture at $37^{\circ} \mathrm{C}$, the cells were collected by centrifuge and washed four times with ten volumes of $0.9 \% \mathrm{NaCl}$

1) E. L. Smith and R.L. Hill, The enzyme (Academic Press Inc.), 4, 37 (1960).

2) J. Fukumoto, et al., J. Agr. Chem. Soc. Japan, 31, 331 (1957), 32, 230, 233 (1958), 33, 6, 9 (1959).

3) J. Fnkumoto, Annual Report of the Institute of Osaka Municipal Res. Tech., 1944, No. 9. solution. The cells thus washed were immediately subjected to lysis with egg white lysozyme in order to extract the peptidase as described later.

The peptidase activity was assayed on DL-Leu. Gly.DL-Phe as substrate. To a mixture of $0.5 \mathrm{ml}$ of $\mathrm{M} / 50$ of the peptide, $0.2 \mathrm{ml}$ of $\mathrm{M} / 5$ tris(hydroxy. methyl)aminomethane-HCl buffer (Tris buffer, $\mathrm{pH}$ 7.5) and $0.1 \mathrm{ml}$ of $\mathrm{M} / 40 \mathrm{MnCl}_{2}$ was added $0.1 \mathrm{ml}$ of enzyme at $25^{\circ} \mathrm{C}$. After $2.5 \mathrm{~min} ., 0.1 \mathrm{ml}$ of $\mathrm{N} / 2 \mathrm{HCl}$ was added to the mixture and $0.1 \mathrm{ml}$ aliquot of the mixture was taken into $1.4 \mathrm{ml}$ of citrate buffer of $\mathrm{pH} 5.0$ and subjected to the ninhydrin reaction test according to the Yemm and Cocking's method. ${ }^{4)}$ One unit of enzyme activity was defined as the enzyme quantity that produced $1.0 \mu$ mole of amino acid per min. under the condition. In Fig. 1 is shown the relationship between the enzyme quantities and the degree of liberation of amino acids in the mixture under the condition. The specific activity was expressed arbitrarily as the enzyme activity per one unit of absorbancy of enzyme protein at $280 \mathrm{~m} \mu$ using the silica cuvette of one cm light path.

In the test of the effect of metal ions on the enzyme, a peptide isolated from polypepton (Daigo Eiyo Kagaku Co., Ltd., Japan) was used as the substrate. The polypepton was dissolved in deionized water and, after adjusting the $\mathrm{pH}$ to 2.5 with $\mathrm{HCl}$, dialyzed using a cellulose tubing (Visking Company) against frequently changing solution of dilute hydrochloric acid ( $\mathrm{pH} 2.5$ ) for 5 days in the cold. The two dimensional paperchromatography of the dialyzed

4) E. M. Yemm and E. C. Cocking, Analyst, 80, 209 (1955). 


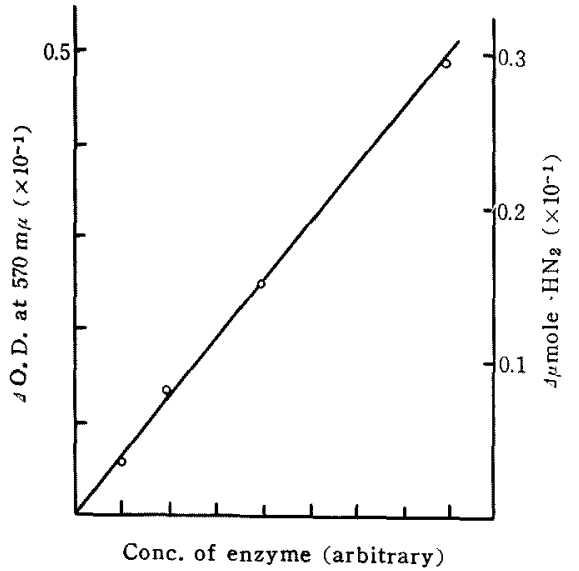

FIG. 1. Enzyme Concentration and Amino Acid Liberation.

polypepton showed to contain only two peptides, their $R_{F}$ being very close each other and giving nine kinds of amino acid on acid hydrolysis.

The crystalline egg white lysozyme $\left([E]_{1 \%}^{20 u m \mu}=24.5\right)$ used here was prepared according to the modified method of Alderton.5)

\section{RESULTS}

\section{Extraction and purification of the enzyme}

The washed bacterial cells were suspended in $\mathrm{M} / 50$ phosphate buffer of $\mathrm{pH} 7.2$ containing M/200 ethylenediaminetetraacetic acid sodium salt (EDTA) and incubated with an appropriate amount of lysozyme (usually $2 \sim 3 \mathrm{mg}$ of lysozyme for one $g$ of the cells as dry weight) at $37^{\circ} \mathrm{C}$ for one $\mathrm{hr}$. The lyzed cell mixture was frozen and stored at $-20^{\circ} \mathrm{C}$ for two days. The frozen preparation was then thawed at room temperature and centrifuged at $67,000 \mathrm{~g}$ for $30 \mathrm{~min}$. $\left(0^{\circ} \mathrm{C}\right)$. To the supernatant solution was added solid ammonium sulfate to a 0.5 saturation and the mixture was centrifuged at $15,000 \mathrm{~g}$, whereby very viscous material was precipitated. The clear supernatant was then salted out by supplemental addition of solid ammonium sulfate to a 0.8 saturation. The precipitate there occurred was collected by centrifugation at

5) G. Alderton, Biochemical Preparation, 1, 67 (1950).
$15,000 \mathrm{~g}$ and dialyzed under stirring against changing $\mathrm{m} / 20$ acetate buffer of $\mathrm{pH} 5.8$ containing $\mathrm{m} / 400$ magnesium acetate for two days. The dialyzed enzyme was then subjected to diethylaminoethyl(DEAE)-cellulose column chromatography.

To the DEAE-cellulose column $(1.8 \times 42 \mathrm{~cm})$, which had been equilibrated with the buffer of the same constituents as those used in the dialysis, the enzyme was applied and developed by linear gradient elution with a mixing chamber containing $0.5 \mathrm{I}$ of $0.05 \mathrm{M}$ $\mathrm{NaCl}$ and a reservoir containing 0.51 of $0.5 \mathrm{M}$ $\mathrm{NaCl}$ in the buffer at a flow rate of $80 \mathrm{ml}$ per hr. at $4^{\circ} \mathrm{C}$. The chromatogram is shown in Fig. 2.

The active enzyme fractions obtained in the column chromatography were combined together and dialyzed against buffer solution of the same constituents as those used in the dialysis before. The dialyzed enzyme was again chromatographed using DEAE-cellulose column, the chromatographic pattern showing almost only one peak in regard either to protein or enzyme activity (Fig. 3).

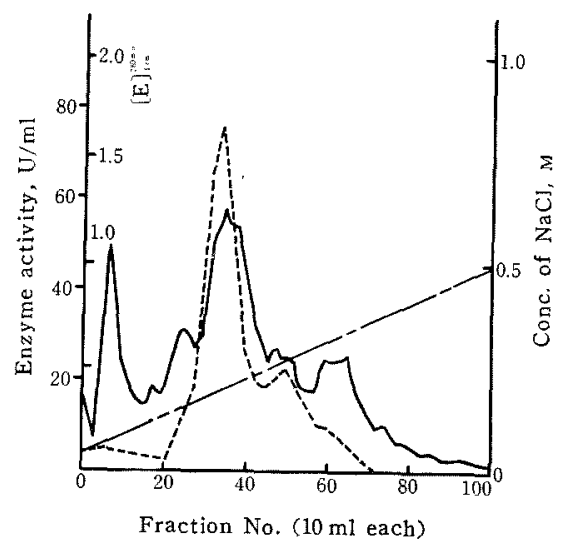

FIG. 2. Chromatograms of Bac. subtilis' Peptidase on a DEAE-Cellulose Column $(1.8 \times 42 \mathrm{~cm}$; enzyme applied, $85 \mathrm{ml}(11,000 \mathrm{U}))$.

$$
\text { -. }[E]_{1 \mathrm{~cm}}^{280 \mathrm{~m} \mu} ;-.-, \text {, enzyme activity, }
$$




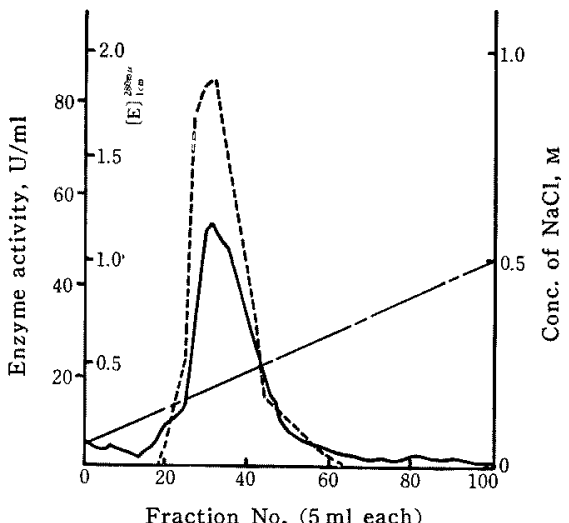

FIG. 3. Rechromatography of the Peptidase on a DEAE-Cellulose Column $(1.2 \times 30 \mathrm{~cm}$; enzyme applied, $167 \mathrm{ml}(8,900 \mathrm{U}))$.

$$
\text { -. }[E]_{1 \mathrm{~cm}}^{280 \mathrm{~m} \mu} ;--- \text {, enzyme activity, }
$$$$
\text { - Conc. of } \mathrm{NaCl}
$$

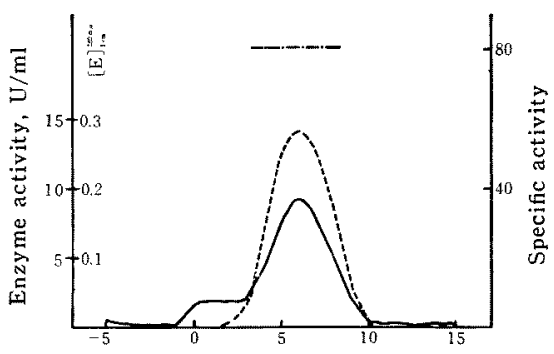

Distance migrated $(\mathrm{cm})$

FIG. 4. Zone Electrophoresis of the Peptidase on a Starch Block.

$-[E]_{1 \mathrm{~cm}}^{280 \mathrm{em}} ;---$. Enzyme activity,

-...... Specific activity,

Starch block, $1.5 \times 3.0 \times 20 \mathrm{~cm}$; $/ 20$ acetate buffer $(\mathrm{pH} 5.6)$ containing $\mathrm{M} / 400 \mathrm{Mg}$-Acetate; $300 \mathrm{~V}, 20 \mathrm{~mA} ; 6 \mathrm{hr}$ at $4^{\circ} \mathrm{C}$, Enzyme charged, $220 \mathrm{U}$ of rechromatographed preparation.
The zone electrophoresis on a starch block revealed that the rechromatographed enzyme preparation was almost homogeneous, as shown in Fig. 4. However, the purified peptidase still showed a slight activity of proteinase when assayed by the modified Folin's method, ${ }^{21}$ but this proteinase activity was nullified by treating the preparation with EDTA or potato proteinase inhibitor, giving no effect on the peptidase activity of the enzyme preparation (Table I). The purification procedure described above is summarized in Table II.

TABLE I. EFFECT OF EDTA AND Potato ProteINASE INHIBITOR (PPI) ON THE PURIFIEd Pertidase

\begin{tabular}{|c|c|c|c|}
\hline \multirow[b]{2}{*}{$\begin{array}{l}\text { Substrate } \\
\text { Treatment } \\
\left(25^{\circ} \mathrm{C}, 30 \mathrm{~min} .\right)\end{array}$} & \multicolumn{3}{|c|}{ Enzyme activity } \\
\hline & $\begin{array}{l}\text { Leu. Gly. } \\
\text { Phe* }\end{array}$ & $\begin{array}{c}\text { Polypeptide* } \\
\text { from } \\
\text { polypepton }\end{array}$ & Casein** \\
\hline No & $55 \mathrm{U} / \mathrm{ml}$ & $5.0 \mathrm{U} / \mathrm{ml}$ & $3.2 \mathrm{U} / \mathrm{ml}$ \\
\hline EDTA & 67 & 4.2 & 0 \\
\hline PPI & 51 & 4.1 & 0 \\
\hline $\begin{array}{l}\text { EDTA }(M / 250) \\
+ \text { PPI }\end{array}$ & 70 & 4.2 & 0 \\
\hline
\end{tabular}

\section{Some properties of the enzyme}

The purified peptidase was found to act best at $\mathrm{pH}$ 7.5, as shown in Fig. 5. In the presence of $\mathrm{Mg}^{++}$, the enzyme was stable at $\mathrm{pH}$ values between 5.5 and $8.0\left(25^{\circ} \mathrm{C}, 16 \mathrm{hr}\right.$, Fig. 6). However, the enzyme was sensitive to heat and lost a half of its activity even at $60^{\circ} \mathrm{C}(\mathrm{pH} 7.2)$ in $10 \mathrm{~min}$. (Fig. 7).

Table II. Summary of Purification Procedure of Bac. subtilis' PePtidase

\begin{tabular}{lcccccc} 
Step & Activity & Total volume & Total activity & Specific & \multicolumn{2}{c}{$\begin{array}{c}\text { Recovery } \\
\text { activity }\end{array}$} \\
lysis & $\begin{array}{c}\mathrm{U} / \mathrm{ml} \\
\mathrm{ml}\end{array}$ & 750 & $11,000(4,800)$ & $0.48(0.21)$ & $100(100)$ \\
matography & $150(6.4)$ & 85 & $11,000(3,900)$ & 7.1 & $(2.6)$ & $100(80)$ \\
ma-cellulose) & $53(6.0)$ & 167 & $8,900(1,000)$ & 68 & $(7.7)$ & $81(21)$ \\
romatography & $73(8.1)$ & 60 & $4,400(490)$ & 81 & $(9.0)$ & $41(10)$
\end{tabular}

The number in parenthesis indicates the enzyme activity on the polypeptide. See the text. 


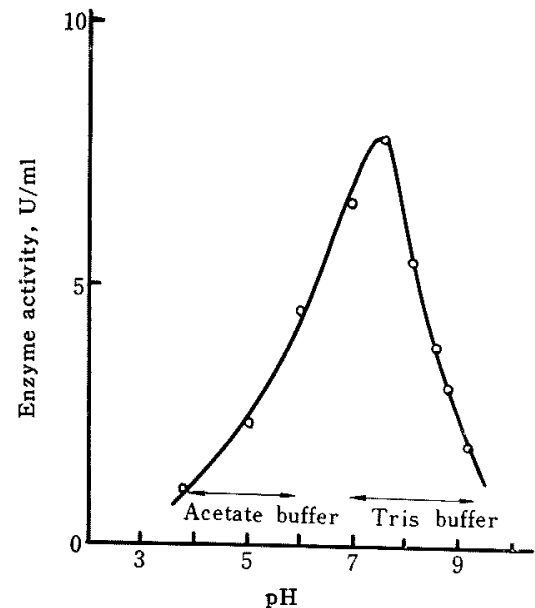

FIG. 5. pH-Activity Curve.

(DL-Leu-Gly·DL-Phe, $\mathrm{M} / 360 \mathrm{MnCl}_{2}$ )

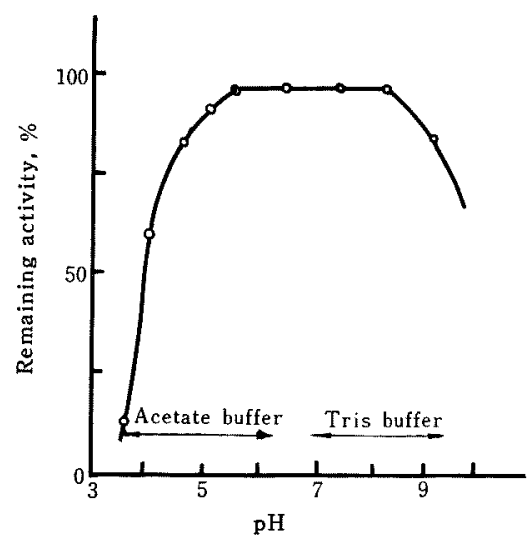

Fig. 6. pH-Stability.

$\left(\mathrm{Mg}^{++}, \mathrm{M} / 500\right)$

The enzyme, purified as above and finally dialyzed against Tris buffer, showed no enzyme activity but, was activated by the addition of divalent metal ions. The best reactivation was observed by the addition of $\mathrm{Mn}^{++}$to the reaction mixture as given in Table III. The effect of $\mathrm{Mn}^{++}$or $\mathrm{Co}^{++}$was significantly distinct with the enzyme which had been pretreated with EDTA. The EDTA-treated enzyme preparation showed no reactivation by any metal ion other than $\mathrm{Mn}^{++}$or $\mathrm{Co}^{++}$

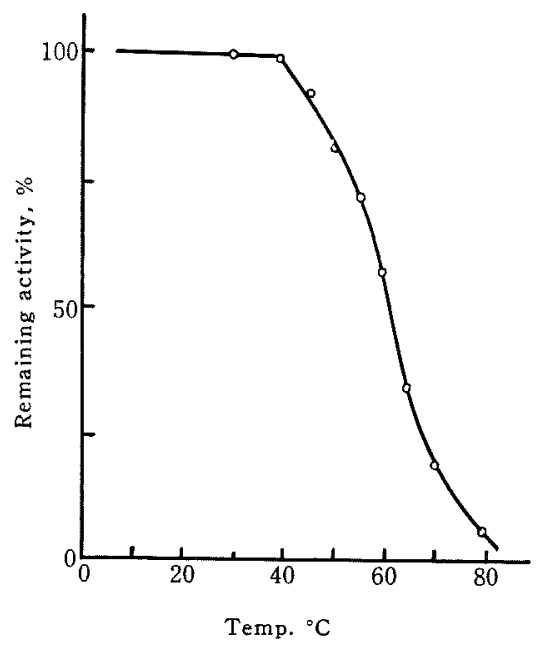

FIG. 7. Thermal Stability.

(pH 7.2, $\mathrm{M} / 50$ Tris buffer, $\mathrm{M} / 400 \mathrm{MgCl}_{2}, 10 \mathrm{~min}$.)

TABLE III. EFFECT OF VARIOUS METAL IONS ON ENZYME ACTIVITY*

\begin{tabular}{|c|c|c|c|}
\hline $\begin{array}{l}\text { Pretreatment } \\
\text { of enzyme }\end{array}$ & $\begin{array}{l}\text { Metal added } \\
\text { (Acetate, } \\
\text { M/250) }\end{array}$ & $\begin{array}{c}\text { Enzyme } \\
\text { activity } \\
\text { U }\end{array}$ & $\begin{array}{c}\text { Relative } \\
\text { activity } \\
\%\end{array}$ \\
\hline \multirow{7}{*}{ No } & None & 0 & 0 \\
\hline & $\mathrm{Mg}$ & 0.3 & 5.6 \\
\hline & $\mathrm{Ca}$ & 0.3 & 5.6 \\
\hline & Co & 3.2 & 63 \\
\hline & $\mathrm{Mn}$ & 5.0 & 100 \\
\hline & $\mathrm{Zn}$ & 0 & 0 \\
\hline & $\mathrm{Ni}$ & 0.4 & 7.8 \\
\hline \multirow{7}{*}{$\begin{array}{l}\text { Preincubated } \\
\text { with M/500 } \\
\text { EDTA (pH7 .6, } \\
30^{\circ} \mathrm{C} \text {, 1hr) }\end{array}$} & None & 0 & 0 \\
\hline & $\mathrm{Mg}$ & 0 & 0 \\
\hline & $\mathrm{Ca}$ & 0 & 0 \\
\hline & Co & 1.5 & 30 \\
\hline & $\mathrm{Mn}$ & 4.1 & 83 \\
\hline & $\mathrm{Zn}$ & 0 & 0 \\
\hline & $\mathrm{Ni}$ & 0 & 0 \\
\hline
\end{tabular}

* Assayed on the peptides isolated from polypepton.

In the test of the relationship between the concentration of $\mathrm{Mn}^{++}$and the enzyme activity was used, as substrate, the peptide that was isolated from polypepton. The peptidase purified as above showed activity on these peptides only in the presence of $\mathrm{Mn}^{++}$or $\mathrm{Co}^{++}$. The enzyme activity as a function of 
the concentration of $\mathrm{Mn}^{++}$is shown in Fig. 8. However, the synthetic peptides used here were contaminated by certain metals and thus no clear result was found with them on the requirement of metal ions of the enzyme.

On the other hand, the stability of the enzyme, especially during dialysis, was greatly affected by the sort of divalent metal ions present in the outer solution, as given in Table IV The best stability of the enzyme was bestowed by $\mathrm{Mg}^{++}$whereas the presence of $\mathrm{Mn}^{++}$or $\mathrm{Co}^{++}$rather caused a considerable loss of enzyme activity during dialysis.

The ultraviolet absorption spectra of the purified peptidase are shown in Fig. 9.

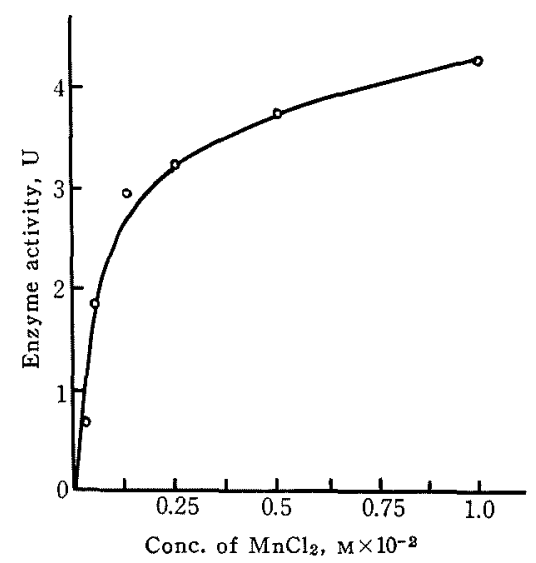

FIG. 8. Enzyme Activity as a Function of Concentration of $\mathrm{Mn}^{++}$.

TABLE IV. EFFECT OF VARIOUS DIVALENT METAL IONS ON ENZYME STABILITY DURING DIALYSIS $\left(4^{\circ} \mathrm{C}, 40 \mathrm{hr}\right.$.)

\section{Outer solution}

Deionized water M/200 Tris buffer, $\mathrm{pH} 7.2$

n $+M / 400$ Mn-acetate

" $+M / 400 \mathrm{Mg}$-acetate

n $\quad+\mathrm{M} / 400 \mathrm{Ca}$-acetate

" $+\mathrm{M} / 400$ Co-acetate

" $+\mathrm{M} / 400 \mathrm{Zn}$-acetate
Survival activity

$$
\%
$$

96

42

100

77

50

0

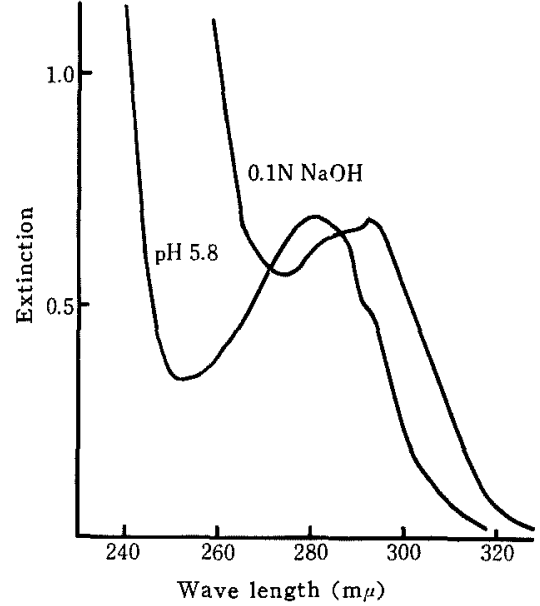

FIG. 9. Ultraviolet Absorption Spectra of Bac. subtilis' Peptidase.

$(0.11 \mathrm{mgN} / \mathrm{ml}, 60 \mathrm{U}$ of activity/ml)

\section{Specificity of the enzyme}

The specificity of the peptidase was investigated using the enzyme preparation treated with EDTA and making to react with various synthetic peptides under the following condition: A $0.1 \mathrm{ml}$ of enzyme $\left([E]_{\mathrm{cm}}^{280 \mathrm{~m} \mu}=0.35\right)$ was added to a mixture of $0.05 \mathrm{ml}$ of peptide solution (approx. $1 \mu \mathrm{mole}$ ) and $0.05 \mathrm{ml}$ of $\mathrm{M} / 25$ Tris buffer ( $\mathrm{pH} 8.0$ ) containing $\mathrm{M} / 100 \mathrm{MnCl}_{2}$. After incubation for $20,120 \mathrm{~min}$. and $24 \mathrm{hr}$. at $25^{\circ} \mathrm{C}$, a $0.02 \mathrm{ml}$ aliquot of the reaction mixture was spotted on a filter paper of Toyo No. 50 and developed at $25^{\circ} \mathrm{C}$ by the descending method using a mixture of butanol, acetic acid and water $(4: 1: 2)$ as the solvent. The paper was then dried in a current air and sprayed by a $0.2 \%$ solution of ninhydrin dissolved in butanol saturated with water. As given in Table $\mathrm{V}$, the enzyme hydrolyzed various peptides, excepting DL-Ala.DL-Val, although the rate of hydrolysis differed according to the kind of peptide.

The peptidase also hydrolyzed D-amino acid peptides, but the hydrolysis rate was much slower than that of L-amino acid as presented in Fig. 10. However, no hydrolysis was found 
Table 5. action on Various Synthetic Peptides (Part 1 )

\begin{tabular}{|c|c|}
\hline Peptide & Activity \\
\hline DL-Ala.Gly & ++ \\
\hline DL-Ala.Gly.Gly & + \\
\hline $\mathrm{DL}-\mathrm{Ala} \cdot \mathrm{DL}-\mathrm{Val}$ & - \\
\hline$\alpha$-amino-Buty $\cdot$ Gly & +++ \\
\hline Gly-DL-Ala & + \\
\hline Gly-L-Asp & ++ \\
\hline Gly $\cdot$ Gly & + \\
\hline Gly $\cdot$ Gly $\cdot$ Gly & + \\
\hline Gly.Gly·Gly:Gly & + \\
\hline Gly·L-Leu & ++ \\
\hline Gly·DL-Phe & ++ \\
\hline Gly - DL-Phe- $\mathrm{NH}_{2}$ & + \\
\hline
\end{tabular}

Peptide

Gly $\cdot \mathbf{L}-\operatorname{Try}$

Gly $\cdot \mathrm{L}-\mathrm{Tyr}$

$\mathrm{Gly} \cdot \mathrm{L}-\mathrm{Val}$

L-Leu-NH$H_{2}$

L-Leu.Gly

L-Leu.L-Tyr

$\mathrm{Cbz}-\mathrm{Gly} \cdot \mathrm{Gly}-\mathrm{NH}_{2}$

Cbz-Gly-L-Phe

$\mathrm{Cbz}-\mathrm{Gly} \cdot \mathrm{L}-\mathrm{Phe}-\mathrm{NH}_{2}$

Cbz-L-Leu.Gly

Hippuryl-L-Leu- $\mathrm{NH}_{2}$
Activity

$+$

$+$

$+$

$+$

$++$

$+t$

-

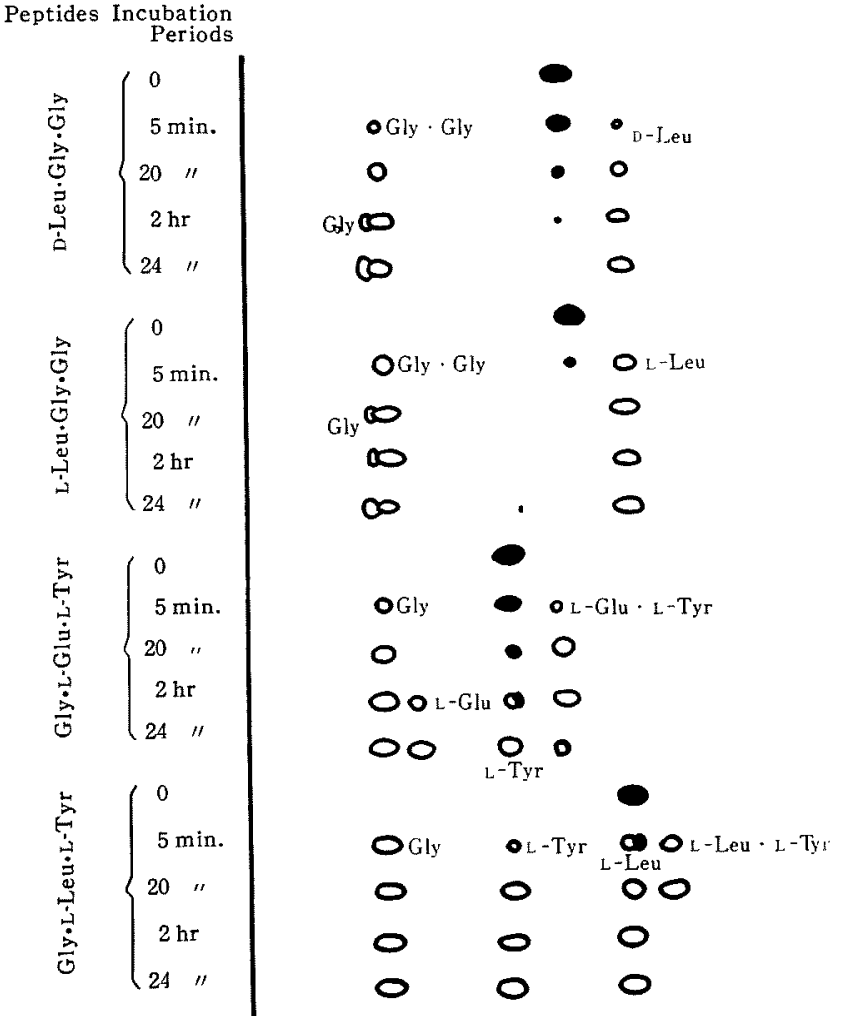

FIG. 10. Action on Various Synthetic Peptides (Part II). 
with any peptide whose terminal amino groups were blocked.

In Fig. 11 is shown the progressive curve of hydrolysis of DL-Leu.Gly.DL-Phe by the peptidase. To a mixture consisting of $0.1 \mathrm{ml}$ of $\mathbf{M} / 50 \mathrm{DL}-\mathrm{Leu} \cdot \mathrm{Gly} \cdot \mathrm{DL}-\mathrm{Phe}, 0.1 \mathrm{ml}$ of $\mathrm{m} / 40$ $\mathrm{MnCl}_{2}$ and $0.1 \mathrm{~mL}$ of $\mathrm{M} / 50$ Tris buffer ( $\mathrm{pH} 8.0$ ) was added $0.1 \mathrm{ml}$ of the peptidase $\left([E]_{\mathrm{cm}}^{280 \mathrm{~m} \mu}=\right.$ 0.9 ) and, at varied intervals of time at $25^{\circ} \mathrm{C}$, $0.01 \mathrm{ml}$ aliquots were taken to spot on a filter paper of Tôyô No. 50 and paperchromatographed as described above. After color development by spraying ninhydrin solution, the color density was measured using a densitometer (Tôyô Densitol) to determine the amount of liberated amino acid, comparing with the color derived from a given amount of amino acid applied as a marker. The result shown in Fig. 11 indicates that on hydrolysis of DL-Leu.Gly.DL-Phe by the peptidase a rapid liberation of leucine occurred, leaving behind Gly·DL-Phe peptide there. However, the latter was gradually hydrolyzed to its constituting amino acids in the subsequent

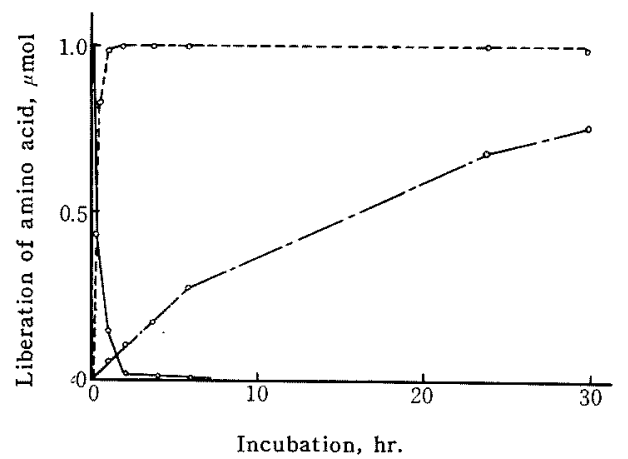

FIG. 11. Progressive Curve of Hydrolysis of DLLeu.Gly.DL-Phe.

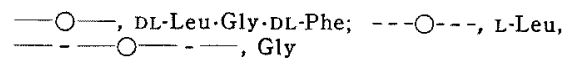

incubation. In the experiment, the rate of hydrolysis of leucyl peptide linkage was calculated to be about one hundred times faster than that of glycyl peptide.

\section{DISCUSSION}

The peptidase isolated from the cells of Bac. sbutilis was found to hydrolyze various peptides. The facts, that the enzyme hydrolyzed only the peptides, of which amino group of the terminal amino acid was free, and that the hydrolysis progressed to liberate amino acid from the amino terminal amino acid of the peptides, clearly indicate that the enzyme is an aminopeptidase. This enzyme might be classified into leucyl aminopeptidase, because it acted best on leucyl peptides.

However, in contrast to leucine aminopeptidase isolated from swine kidney by Smith and Spackman, ${ }^{61}$ the enzyme in the present paper hydrolyzed leucyl peptide much faster than leucine amide (The $C_{1}$ of the peptidase which was determined according to the method of Smith $^{6}$ was 14.3 on DL-Leu.Gly.DL-Phe whereas it was 0.22 on Leu- $\mathrm{NH}_{2}$ ) and showed activity only in the presence of $\mathrm{Mn}^{++}$and $\mathrm{Co}^{++}$No enzyme activity was found in the presence of $\mathrm{Mg}^{++}$alone, although the enzyme was stabilized by the metal ion.

In other experiments, the peptidase was found to hydrolyze polypeptides or denaturated proteins deeply but the hydrolysis ceased at certain points. This reason and the detailed nature of the peptidase are now under investigation.

Acknowledgement. The authors are indebted to Mr. Y. Sasaki and Y. Matsumura for their assistance in part of the experiment.

6) E. L. Smith and D. H. Spackman, J. Biol. Chem., 212, 271 (1955). 